\title{
Tumori nakon transplantacije bubrega
}

\section{Malignancies in renal transplant recipients}

\author{
Tea Vukić ${ }^{1}$, Željko Kaštelan $^{2}$, Ivana Jurić ${ }^{1}$, Vesna Furić-Čunko ${ }^{1}$, Nikolina Bašić-Jukić ${ }^{1^{*}}$
}

${ }^{1}$ Zavod za nefrologiju, arterijsku hipertenziju, dijalizu i transplantaciju, Klinički bolnički centar Zagreb, Medicinski fakultet Sveučilišta u Zagrebu, Zagreb, Hrvatska

${ }^{2}$ Klinika za urologiju, Klinički bolnički centar Zagreb, Medicinski fakultet Sveučilišta u Zagrebu, Zagreb, Hrvatska

\section{"Dopisni autor:}

Prof. dr. sc. Nikolina Bašić Jukić, dr. med.

Zavod za nefrologiju, arterijsku hipertenziju, dijalizu i transplantaciju,

Klinički bolnički centar Zagreb,

Kišpatićeva 12, 10000 Zagreb

E-mail: nbasic@kbc-zagreb.hr
Sažetak. Završni stadij kronične bubrežne bolesti zahtijeva liječenje nadomještanjem bubrežne funkcije različitim metodama, od kojih je najbolja transplantacija bubrega, zbog značajno više stope preživljavanja i kvalitete života u usporedbi $s$ dijalizom. U početcima transplantacijske medicine, kada su transplantacije izvođene samo u mlađih pacijenata, a preživljenje presatka bilo relativno kratko zbog visoke stope akutnih odbacivanja, zloćudni tumori predstavljali su manje važan problem. Vodeći uzrok gubitka presatka u vrijeme suvremene imunosupresije je smrt pacijenata s funkcionirajućim presatkom, a upravo su zloćudni tumori, nakon srčanožilnih bolesti i infekcija, na trećem mjestu uzročnika smrti u populaciji pacijenata s transplantacijom koja je sve starija i pod sve dužim kumulativnim djelovanjem imunosupresiva. Prema podatcima Registra za transplantaciju Australije i Novog Zelanda $10 \%$ pacijenata razvije tumor nakon 10 godina, $25 \%$ nakon 20 godina, a nakon 30 godina čak $40 \%$ primatelja bubrega pod imunosupresivnom terapijom razvije tumor. $U$ kohorti od 175000 primatelja u Sjedinjenim Američkim Državama je identificirano 10656 tumora, što je 2,1 puta više nego u općoj populaciji. Uočen je značajan porast rizika za više od 30 različitih primarnih tumora te snižena incidencija tumora dojke i prostate u odnosu na opću populaciju.

\section{Ključne riječi: imunosupresija; transplantacija bubrega; zloćudni tumor}

Abstract. End-stage renal disease requires the replacement of kidney function by different methods, the best of them being renal transplantation owing to significant survival advantage and better quality of life compared to the dialysis. In the beginnings of transplantation medicine, when transplantation was performed solely in young patients, and survival was relatively short due to acute rejections, malignant tumors were not a significant problem. In the era of modern immunosuppression, the leading cause of graft lost is death of a patient with functional graft. Malignant tumors are the third leading cause of death in patients following renal transplantation due to the increasing age of patients undergoing renal transplantation and longer cumulative influence of immunosuppression. Cardiovascular diseases and infections are the first and a second leading cause of death, respectively. According to Australian and New Zealand Dialysis and Transplant Registry, 10\% of patients develop tumor 10 years after transplantation, 25\% after 20 years, and after 30 years $40 \%$ of renal transplant recipients treated with immunosuppression develop malignancy. In a large population-based cohort study of 175000 United States transplant recipients of solid organs, among those 10656 developed some kind of a tumor. This is 2.1 times more often when compared to the general population. A significant increase of risk for 30 different primary tumors was reported, whereas a decreased incidence of breast cancer and prostate cancer was noted.

Key words: immunosuppression; malignant tumor; renal transplantation 
ETIOLOGIJA I PATOGENEZA TUMORA

NAKON TRANSPLANTACIJE BUBREGA

Tumori u pacijenata s transplantiranim bubregom mogu se pojaviti de novo, može doći do recidiva prethodno liječenog tumora ili mogu biti preneseni s darovatelja bubrega ${ }^{1-4}$. Retrospektivne studije pokazuju da primatelji bubrega imaju rizik od $1,3 \%$ od prijenosa neprepoznatog tumora s darovatelja, 0,2 \%-tni rizik od razvoja de novo neoplazme te rizik od $45 \%$ da će se u njih razviti tumor ako dobiju presadak od darovatelja s poznatim tumorom ${ }^{5-8}$. Najviša stopa povrata zloćudnog tumora zabilježena je $u$ pacijenata $s$ karcinomom dojke, simptomatskim karcinomom bubrega, tumora mokraćnog mjehura i multiplim mijelomom. Jasno je da pacijenti s anamnezom zloćudnog tumora imaju povišeni posttransplantacijski rizik od povrata tumora-11. Dogovoreno vrijeme čekanja pokušaj je da se rizik za povrat tumora smanji na najmanju moguću mjeru, a istodobno smanji rizik da pacijent umre na dijalizi zbog srčanožilnih bolesti ${ }^{12,13}$. Analizom američke baze UNOS dokazan je prijenos zloćudnog tumora u 9 od 34933 darovatelja. Posrijedi je bio melanom, tumor pluća, onkocitom i papilarni karcinom nepoznatog primarnog sijela. Zabilježena su i dva slučaja prijenosa karcinoma dojke i pluća u živih darovatelja. Problem neprepoznavanja zloćudnog tumora u darovatelja javlja se radi kasnog kliničkog manifestiranja u živog darovatelja ili se otkrije pri obdukciji umrlog darovatelja koja se često i propusti,18,19. Analizom Pennova registra došlo se do podataka da je većina tumora bila prenesena upravo s darovatelja koji su umrli od intrakranijalnog krvarenja koje je u osnovi bilo krvarenje iz neprepoznate metasta$\mathrm{ze}^{14,15}$. Etiologija razvoja tumora je multifaktorijalna i povezana s korištenjem imunosupresivne terapije. Čimbenici rizika uz imnosupresiju su genetički čimbenici, vrijeme provedeno na dijalizi, vrijeme provedeno na imunosupresivnim lijekovima, okolinski čimbenici te virusne infekcije $e^{16-20}$. Onkogeni virusi onemogućuju apoptozu, što potiče daljnji razvoj tumora. Predtransplantacijski probir na virusne infekcije može biti koristan radi prepoznavanja visokorizičnih pacijenata ${ }^{1,21-25}$. Najizraženiji primjer djelovanja čimbenika okoliša na razvoj tumora jest djelovanje UV zračenja, radi čega je izrazito visok broj oboljelih od tumora kože u Australiji i Novom Zelandu, kao i mediteranskim zemljama ${ }^{22,26}$. Pušenje je važan čimbenik okoliša koji povećava rizik od razvoja tumora, kao i povećanje životne dobi te vrijeme provedeno na dijalizi ${ }^{4,20}$. Rizik od razvoja tumora dojke i jajnika te tumora prostate manji je nego u općoj popula$\mathrm{ciji}^{25}$.

Etiologija razvoja tumora koji se razvijaju u pacijenata s transplantiranim bubregom je multifaktorijalna i povezana s korištenjem imunosupresivne terapije. Riziku pridonose i genetički čimbenici, vrijeme provedeno na dijalizi, vrijeme provedeno na imunosupresivnim lijekovima, okolinski čimbenici te virusne infekcije.

\section{IMUNOSUPRESIVNI LIJEKOVI}

Ishod transplantacije ovisi o složenom i dinamičnom odnosu između imunosupresije s infekcijama, zloćudnim bolestima i ostalim komplikacijama. Primarni cilj jest održati najnižu moguću razinu imunosupresije kojom se sprječava akutno odbacivanje, a na najmanju moguću mjeru svesti moguće komplikacije liječenja. Imunosupresivnim lijekovima želimo inhibirati imunosne stanice, staničnu funkciju te potisnuti protuupalne citokine ${ }^{23-25}$. Prva uspješna transplantacija učinjena je na jednojajčanim blizancima upravo radi zaobilaženja imunosnog odgovora organizma na strane antigene. Transplantacija među imunološki različitim osobama omogućena je uvođenjem azatioprina u kombinaciji sa steroidima šezdesetih godina prošlog stoljeća, ali uz vrlo visoke stope akutnih odbacivanja. Tek uvođenje ciklosporina u imunosupresijske protokole osamdesetih godina omogućilo je transplantaciju bubrega kakvu poznajemo danas. Mnogo godina je trojna terapija imunosupresivima smatrana zlatnim standardom imunosupresije. Ipak, sve se više nameće problem toksičnosti ovih lijekova, među kojima je i povećana incidencija nastanka zloćudnih novotvorina. Ne postoji univerzalan imunosupresijski protokol, nego je liječenje potrebno individualizirati s obzirom na obilježja primatelja, ali i darovatelja organa ${ }^{26,27}$. 
Nakon transplantacije bubrega može doći do razvoja bilo kojega malignog tumora, ali ipak se može uočiti određena zakonitost u njihovoj pojavnosti s obzirom na vrijeme nakon transplantacije ${ }^{23}$. U prvim se mjesecima nakon transplantacije najčešće pojavljuju posttransplantacijske limfoproliferativne bolesti, dok se dvadesetak i više godina od transplantacije najčešće pojavljuju tumori kože ${ }^{24}$. Starenjem populacije sve više osoba starije životne dobi zahtijeva nadomještanje bubrežne funkcije, pa i transplantacijsko liječenje, zbog čega se tumori kože javljaju sve ranije nakon transplantacije bubrega. Imunosupresivni lijekovi svojim djelovanjem potiču razvoj tumora. Neki od njih imaju antitumorsko djelovanje, poput m-TOR inhibitora ${ }^{28}$. Nekoliko posrednih dokaza govori o odnosu inteziteta imunosupresije i rizika od razvoja tumora nakon transplantacije bubrega:

- rizik od razvoja posttransplantacijske limfoproliferativne bolesti najviši je u prvoj godini nakon presadbe, kada je i najviši intenzitet imunosupresije;

- rizik od razvoja tumora viši je u primatelja srca koji zahtijevaju intenzivniju imunosupresiju od primatelja bubrega;

- nađena je korelacija razvoja tumora i doze ciklosporina;

- imunosupresijski protokoli s indukcijom poliklonalnim antitijelima i trojnom terapijom imaju veću pojavnost tumora od standardne trojne terapije;

- nađena je povezanost između CD4 limfopenije i povećanja rizika od tumora kože;

- rizik od razvoja tumora raste s kumulativnom izloženosti imunosupresivnoj terapiji ${ }^{1}$.

Određena vrsta imunosupresije češće je povezana $s$ razvojem tumorskih stanica. Liječenje poliklonalnim protutijelima u sklopu indukcijske terapije povećava rizik od razvoja malignih bolesti. Ova protutijela uzrokuju lizu limfocita djelujući na učinkovitost imunosnog nadzora. Tako su posttransplantacijske limfoproliferativne bolesti inducirane Epstein-Barrovim virusom osobito česte u pacijenata liječenih s OKT3. Nasuprot ovome, rituksimab može smanjiti učestalost limfoproliferativnih bolesti ${ }^{1}$. Inhibitori kalcineurina, ciklosporin i takrolimus, važni su čimbenici u poticanju zloćudnih tumora ${ }^{29,30}$. Sirolimus i everolimus su mTOR inhibitori koji djeluju na prolifera- ciju limfocita $T$ te imaju učinak na vaskularni endotelni čimbenik rasta, što im daje potencijalno antineoplastično djelovanje. Od osobite su važnosti u liječenju pacijenata s Kaposijevim sarkomom u kojih dovode do potpune regresije tumora. U više randomiziranih studija pokazano je smanjenje učestalosti tumora u pacijenata liječenih mTOR inhibitorima s obzirom na one liječene inhibitorima kalcineurina ${ }^{31,32}$. Uloga kortikosteroida nije posve jasna, s obzirom na to da se koriste u liječenju limfoma i drugih hematoloških tumora, dok je poznata činjenica kako pacijenti dugotrajno liječeni kortikosteroidima imaju povećan rizik za razvoj Kaposijeva sarkoma. Uporaba belatacepta povezana je s povećanim rizikom od razvoja poslijetransplantacijske limfoproliferativne bolesti u EBV negativnih pacijenata. U suvremenoj medicini, azatioprin je zasjenjen mikofenolatom zbog bolje učinkovitosti. Azatioprin je povezan s razvojem limfoma, tumora mokraćnog mjehura, dojke, mozga i planocelularnim karcinomom kože ${ }^{1}$.

\section{TUMORI NAKON TRANSPLANTACIJE}

Klinička obilježja tumora nakon transplantacije bubrega ovise o primarnom sijelu zloćudnog tumora. Vrijeme prezentacije također ovisi o prirodi tumora, a istraživanja pokazuju kako je prosječno vrijeme pojave tumora 3 godine nakon presadbe bubrega. Pacijenti s transplantacijom imaju lošiju prognozu i veću agresivnost tumora nego u općoj populaciji ${ }^{33-70}$.

Tumori kože najčešći su tumori u pacijenata nakon transplantacije. Najčešće je riječ o nemelanomskim tumorima kože od kojih $90 \%$ čine planocelularni i bazocelularni karcinom kože. Planocelularni karcinom kože učestaliji je od bazocelularnog karcinoma u većini ispitanih populacija, što je u suprotnosti s općom populacijom u kojoj je učestaliji bazocelularni karcinom. Planocelularni karcinom kože javlja se 65 - 250 puta češće kod pacijenata nakon transplantacije nego u općoj populacijijo-52. Oba su tipa agresivnijeg ponašanja i s višim rizikom povrata i zahvaćanja više lokacija. Učestalost ovog tipa tumora raste s vremenom izloženosti imunosupresiji i UV zračenju. Povećava se sa životnom dobi, a tumori su učestaliji u osoba muškog spola i svijetle puti. Čini se 
da je za pojavu tumora važnija ukupna izloženost imunosupresiji od samog tipa imunosupresiva. Pojavljuju se u prosjeku 8 godina nakon transplantacije u primatelja bubrega mlađih od 40 godina, a 3 godine nakon transplantacije u starijih od 60 godina. Imunosupresivi utječu na imunološki nadzor nad keratocitima i pojavnost infekcije HPV-om ${ }^{1,39}$.

Rijetko se pojavljuju i ostali tumori kože poput melanoma, Kaposijeva sarkoma, karcinoma Merkelovih stanica. Rizik je od razvoja melanoma 3,6 puta veći nego u općoj populaciji ${ }^{1}$.

Karcinom Merkelovih stanica agresivni je neuroendokrini karcinom kože koji prije svega zahvaća glavu, vrat i gornje udove i ima lošiji ishod u pacijenata $s$ transplantiranim bubregom. Prosječno vrijeme pojave ovog tumora iznosi 7 godina nakon transplantacije uz prosječno preživljenje od 18 mjeseci $^{1}$. Clarke i sur. u američkoj studiji u koju je uključeno 189498 pacijenata s transplantacijom solidnih organa u razdoblju od 1987. do 2009. godine iznosi kako je cjelokupni rizik od razvoja karcinoma Merkelovih stanica 23,8 puta veći nego u općoj populaciji ${ }^{71}$.

Kaposijev sarkom je tumor koji potječe iz endotelnih stanica ${ }^{40}$. Vrlo je rijedak u općoj populaciji, oko 1000 puta rjeđi nego u pacijenata s infekcijom HIV-om ili u pacijenata s transplantiranim organom. Klinički se očituje purpurnim nodularnim promjenama na koži. Najčešća lokalizacija angiomatoznih promjena jesu potkoljenice, a bolest $u$ 10 \% slučajeva može zahvatiti i unutarnje organe, poput crijeva ili pluća, kada je i prognoza loši$\mathrm{ja}^{35,36}$. Obično se pojavljuje dvije do tri godine nakon presadbe. Triput je učestaliji kod muškaraca. Kaposijev sarkom povezuje se s infekcijom humanim herpesvirusom 8 (HHV 8) $)^{37,38}$. Velikim multicentričnim istraživanjem u Francuskoj dokazano je da postojeća ili stečena infekcija HHV-om 8 nema učinka na preživljenje presatka ili primatelja. To bi značilo da seropozitivni pacijenti ne trebaju biti isključeni iz liječenja transplantacijom bubrega. Upravo je Kaposijev sarkom jasna indikacija za uporabu mTOR inhibitora koji djeluju na vaskularni endotelni čimbenik rasta. $U$ pojedinih je pacijenata indicirana i primjena radioterapi$\mathrm{je}^{57,58}$. U studiji u kojoj je sudjelovalo 400 pacijenata $s$ transplantiranim bubregom, 32 pacijenta bila su pozitivna na anti-HHV8 protutijela, od ko- jih je 28 \% razvilo Kaposijev sarkom tijekom 3 godine. Ostali pacijenti u ovoj studiji, koji nisu imali anti-HHV8 protutijela, nisu razvili Kaposijev sarkom $^{55,56}$.

Na koži se mogu očitovati i drugi tumori.

U zbrinjavanju pacijenata najvažnija je prevencija uz izbjegavanje izlaganja UV zrakama i smanjivanje intenziteta imunosupresije. Svaka sumnjiva lezija mora se kirurški ukloniti i poslati na patohistološku analizu. Preporučena je modifikacija imunosupresije, te se sve više rabe mTOR inhibitori, a izostavljaju inhibitori kalcineurina ${ }^{59}$. Zanimljiva je talijanska studija u kojoj je sudjelovalo 15 pacijenata s transplantiranim bubregom, kojima je biopsijom potvrđen Kaposijev sarkomom te su liječeni ciklosporinom ${ }^{60}$. Terapija ciklosporinom zamijenjena je sa sirolimusom, nakon čega su svi ispitanici u razdoblju od 3 mjeseca imali regresiju kutane lezije Kaposijeva sarkoma bez akutnog odbacivanja presatka ${ }^{61,62}$. Druge studije također potvrđuju korisnost sirolimusa kod ove bolesti, iako se u dužem praćenju pacijenata, može primijetiti povratak bolesti unatoč imunoterapiji sirolimusom ${ }^{63,64}$. Od topičnih pripravaka rabe se interferon alfa, cidofovir, 5-florouracil, podofilin, bleomicin, retinoidi i imiquimod ${ }^{1}$.

Poslijetransplantacijska limfoproliferativna bolest (PTLD) načešći je tumor u djece s transplantiranim bubregom i drugi po učestalosti u populaciji odraslih pacijenata u većini transplantacijskih centara. Pojavnost ove bolesti u pacijenata s transplantiranim bubregom varira od $1 \%$ do $2,5 \%{ }^{66,67}$. Ovim pojmom obuhvaćena je heterogena skupina bolesti u rasponu od difuzne hiperplazije limfocita B do zloćudnih limfoma. Najčešće se pojavljuju tijekom prve godine nakon transplantacije ${ }^{1}$.

Etiologija ove bolesti povezana je s infekcijom Epstein-Barrovim virusom te razinom i vrstom imunosupresije u čijem okruženju limfociti B zaraženi virusom u slučaju zloćudne preobrazbe ne mogu biti eliminirani radi poremećaja u staničnom i humoralnom imunosnom odgovoru. Takve stanice podliježu klonalnoj proliferaciji s posljedičnim razvojem limfoproliferativne bolesti.

U retrospektivnoj studiji u Indiji, u koju je uključeno 2000 pacijenata s transplantiranim bubregom u razdoblju od 1980. do 2010. godine, 40 pacijenata razvilo je neku vrstu maligniteta ${ }^{65}$. Od toga 
je 29 pacijenata razvilo PTLD čineći tako 72,5\% svih tumora razvijenih u ovoj studiji. Ne-Hodgkinov limfom dijagnosticiran je u 22 pacijenta, a mijelom u 7 pacijenata. Samo pet osoba razvilo je bolest u prvoj godini nakon transplantacije, dvanaest pacijenata razvilo je bolest u prvih 5 godina te dvanaest pacijenata u razdoblju od 5. do 10 . godine nakon transplantacije. Suprotno ovome, Cincinnati registar tumora nakon transplantacije izvještava kako PTLD obuhvaća $21 \%$ svih tumora nakon transplantacije, kao i Oxford transplantacijski centar, gdje samo $16 \%$ svih tumora nakon transplantacije čine PTLD ${ }^{69,70}$.

Klasifikacija ove bolesti na nekoliko osnovnih oblika pojednostavljuje shvaćanje o njoj. Najčešći je oblik polimorfni PTLD, gdje atipični limfociti narušavaju normalnu arhitekturu limfoidnog tkiva. Javlja se u prvim godinama nakon transplantacije i povezan je s infekcijom EBV-om. Monomorfni su limfomi neoplazme visokog stupnja, najčešće EBV-om negativne, a javljaju se nekoliko godina nakon transplantacije te prema obilježjima odgovaraju limfomima koji se pojavljuju u općoj populaciji. Difuzna hiperplazija limfocita B obično se viđa u djece i mladih osoba i najčešće uz infekciju EBV-om. Ovaj tip dobro odgovara na snižavanje intenziteta imunosupresije. Ostali oblici PTLD-a su PTLD sličan Hodgkinovom limfomu i PTLD sličan plazmocitomu ${ }^{43}$.

Kliničko očitovanje ove bolesti često odgovara slici limfoma u općoj populaciji i uključuje tzv. B-simptome: vrućicu, noćno znojenje i gubitak tjelesne težine uz perifernu limfadenopatiju. Treba imati na umu javljanje atipičnih prezentacija bolesti u pacijenata koji su imunokomprimitirani poput ekstranodalnih limfoma gastrointestinalnog sustava, kože ili samog transplantata ${ }^{41,42}$. Često se nalazi poremećaj funkcije presađenog bubrega, ali i zahvaćanje središnjeg živčanog sustava, crijeva, pluća ili jetre. U dijagnostici je važno odrediti stadij i gradus bolesti te izraženost EBV-a u tumorskom tkivu, kao i izraženost CD20 na površini stanica imunohistokemijskom analizom.

Liječenje uključuje smanjenje intenziteta imunosupresije. Tridesetak posto pacijenata reagira već na tu prvu terapijsku mjeru. Inhibitor kalcineurina zamjenjuje se sa sirolimusom ili everolimusom uz uporabu antiproliferativnog lijeka, a steroidi se nastavljaju rabiti u istoj mjeri. U difuznim CD20+ oblicima limfoma primjenjuje se rituksimab, himerično monoklonalno protutijelo usmjereno protiv CD20 antigena na limfocitima B. Remisija se postiže u 50 - $60 \%$ pacijenata. Polimorfni oblik ove bolesti zahtijeva primjenu kemoterapije ako nema odgovora na navedene mjere, dok je u monomorfnom obliku kemoterapija prijeko potreban sastavni dio liječenja. Petogodišnje preživljenje iznosi oko 30 do $70 \%{ }^{68}$. Relapsi su česti, a loši prognostički faktori su starija dob, monomorfni oblik i EBV negativan limfom. U studiji Libertinyja i sur. ispitana je pojavnost PTLD-a u 1537 pacijenata s transplantiranim bubregom u razdoblju od 1975. do 1984. godine, kada ciklosporin još nije masovno korišten te je samo jedan pacijent dijagnosticiran S PTLD-om ${ }^{53}$. Od 1984. do 1998. godine, kada se ciklosporin počeo češće koristiti u imunosupresivnoj terapiji, 34 pacijenta dijagnosticirana su s PTLD-om, ukazujući tako na vezu između imunosupresivne terapije i razvoja maligniteta ${ }^{54}$. U studiji USRDS (United States Renal Data System) provedenoj na 66159 primatelja bubrega, PTLD je dijagnosticiran u 1169 pacijenata (1,8\%). Od toga je u njih $70 \%$ bio posrijedi ne-Hodgkinov limfom, u $14 \%$ plazmacitom, u $11 \%$ limfoidna leukemija i u $5 \%$ Hodgkinov limfom $^{1,54}$. Slični rezultati dobiveni su u ANZDATA registru gdje pojavnost PTLD-a iznosi $1,4 \%{ }^{67}$.

Tumori mokraćnog sustava nakon transplantacije mogu se pojaviti u bilo kojemu dijelu mokraćnog sustava, a najčešće se pojavljuju u bubrezima. Može se razviti u vlastitim organima ili u presađenom bubregu. Rizik od razvoja tumora vlastitih bubrega povišen je u pacijenata koji su prethodno dugotrajno liječeni dijalizom, s incidencijom i do 100 puta većom od očekivane. Nije posve jasna povezanost, ali se pretpostavlja da uključuje stvaranje cista, hiperplaziju bubrežnih kanalića i malignu transformaciju nakon dužeg liječenja dijalizom. Upravo su tumori mokraćnog sustava najzastupljenije neoplazme u našoj populaciji pacijenata s transplantiranim bubregom ${ }^{1,44}$.

Pacijenti sa završnim stadijem kronične bubrežne bolesti imaju povišen rizik za razvoj tumora mokraćnog sustava u odnosu prema općoj populaciji jer brojna stanja dovode do zatajivanja bubrežne funkcije i ujedno povećavaju rizik za razvoj tumo$\mathrm{ra}^{1,47}$. Pojavnost karcinoma bubrega u transplanti- 
ranih pacijenata je oko $5 \%$, od kojih $10 \%$ potječe iz presatka ${ }^{72,73}$. Prajwal i sur. analizirali su prikaze slučajeva pacijenata s karcinomom bubrega nakon transplantacije te statističkom obradom podataka dobili da 62 \% karcinoma bubrega potječe od darivatelja, dok se u studiji Pedottija i sur. 19 od 20 slučajeva razvijenog karcinoma bubrega nakon transplantacije pojavilo de novo ${ }^{74-76}$.

Retrospektivnom metaanalizom koja je uključivala 79988 pacijenata iz raznih država uočena je puno viša razina pojavnosti karcinoma mokraćnog mjehura nego u općoj populaciji. Također, postoje razlike između pacijenata iz Europe koji po ovoj studiji imaju duplo veću pojavnost ovog karcinoma i pacijenata u Aziji koji imaju čak 14 puta veću pojavnost, što ukazuje na utjecaj etniciteta $^{77,78}$. Specifičnost našeg područja s obzirom na nefropatiju aristolohične kiseline, tzv. balkanska endemska nefropatija, povećava rizik od razvoja tumora mokraćnog sustava, a pogotovo gornjeg urotela. Pacijenti s endemskom nefropatijom zahtijevaju redovite cistoskopske kontrole radi isključivanja tumora mokraćnog mjehura. U ovih pacijenata preporučena je bilateralna nefroureterektomija te zamjena inhibitora kalcineurina sa sirolimusom ${ }^{45,46}$. Policistična bolest bubrega, stečene ciste bubrega ili analgetska nefropatija također povećavaju rizik od nastanka tumora ${ }^{1,79}$. $U$ studiji sa 65 pacijenata $s$ analgetskom nefropatijom i transplantiranim bubregom, 10 pacijenata je razvilo neku vrstu karcinoma urinarnog trakta $^{79,80}$.

Karcinomi štitnjače često se nalaze u pacijenata $\mathrm{s}$ presađenim bubregom. Većinom je riječ o papilarnim karcinomima-incidentalomima koji su slučajno otkriveni pri dijagnostičkoj obradi paratireoidnih žlijezda. Liječe se operativno i primjenom radiojodne terapije, uz promjenu imunosupresije s inhibitora kalcineurina na mTOR inhibitor, osobito $u$ slučajevima proširene bolesti. Prognoza je dobra ${ }^{1}$. Karamchandani i sur. metaanalizom uključili su 50 861 pacijenta s transplantiranim bubregom i uočili 6,9 puta veći rizik za karcinom štitnjače nego u općoj populaciji. Radilo se o papilarnim karcinomima ${ }^{81-84}$.

Gastrointestinalni tumori poput hepatocelularnog karcinoma javljaju se u pacijenata s kroničnom infekcijom virusom hepatitisa B ili C. Hong i sur. su metaanalizom randomiziranih studija, koja je uključivala 174256 pacijenata s transplantiranim bubregom, uočili duplo veću pojavnost karcinoma jetre $\mathrm{u}$ ovih pacijenata nego $\mathrm{u}$ općoj populaciji ${ }^{85-88}$. Infekcija virusom hepatitisa $\mathrm{C}$ javlja se već kod pacijenata na hemodijalizi, kao i kod pacijenata koji su primili tranfuziju ${ }^{49,89,90}$. Virus hepatitisa B najveći je rizični čimbenik za razvoj hepatocelularnog karcinoma uz virus hepatitisa $\mathrm{C}^{91,92}$.

Pacijenti s anamnezom zloćudnih tumora mogu biti kandidati za transplantaciju bubrega uz vrijeme čekanja koje je individualno za svaku vrstu tumora. Takve pacijente treba pratiti multidisciplinarni tim.

Tumori želudca ili crijeva su rijetkost, kao i karcinom gušterače. Od 509 pacijenata s transplantiranim bubregom 15 pacijenata dijagnosticirano je s adenokarcinomom želuca u studiji Parka i sur. ${ }^{93}$. U kanadskoj bolnici St. Michael analizirano je 1584 pacijenata s transplantiranim bubregom, među kojima je 8 slučajeva adenokarcinoma gastrointestinalnog trakta, 14 displastičnih lezija i 1 slučaj neuroendokrinog tumora ${ }^{48,94}$.

Najveća smrtnost bila je upravo kod ovih pacijenata s tumorom gastrointestinalnog trakta. Prognoza im je loša i povezani su s visokom stopom smrtnosti, kao i u općoj populaciji ${ }^{1}$. Gastrointestinalni stromalni tumori rijetko se javljaju kod pacijenata u transplantaciji; Agaimy i sur. prvi su predstavili dva slučaja gastrointestinalnog stromalnog tumora u pacijenata $s$ transplantacijom bubrega ${ }^{83,84}$. Tu i sur. prezentirali su rijedak slučaj ekstragastrointestinalnog stromalnog tumora lokaliziranog u zdjeličnoj šupljini kod pacijentice $s$ transplantiranim bubregom ${ }^{85}$.

Pacijenti s presađenim bubregom imaju i do 100 puta veći rizik od razvoja tumora anogenitalne regije negoli opća populacija. Tumor može zahvatiti različita mjesta, uključujući anus, kožu perianalne regije i vanjske spolne organe. Klinički se očituje u obliku makulopapularnih promjena. Humani papilomavirus (HPV) je rizični čimbenik za razvoj tumora anogenitalne regije ${ }^{1}$. U sistematskom osvrtu Grulicha i sur. prikazan je porast pojavnosti karcinoma uzrokovanih HPV-om kod 31977 pacijenata nakon transplantacije uspored- 
no s općom populacijom. Pojavnost karcinoma vrata maternice bila je duplo veća, anusa gotovo 5 puta veća, dok je pojavnost karcinoma vulve, vagine i penisa i preko 15 puta veća kod transplantiranih pacijenata s HPV infekcijom ${ }^{95-97}$.

\section{PREVENCIJA I LIJEČENJE}

Prevencija i liječenje trebaju biti fokusirani na nekoliko glavnih područja; predtransplantacijski probir darovatelja i primatelja, poslijetransplantacijski probir primatelja, modulaciju imunosupresivne terapije kako bi se smanjio rizik od pojave tumora, a spriječio razvoj akutnog odbacivanja te specifično zbrinjavanje pojedinih tumo$\mathrm{ra}^{1}$. Svaki transplantacijski centar ima svoj protokol o probiru na zloćudne bolesti, a većina se zasniva na individualnom pristupu pacijentu. Preporučeno je redovito praćenje promjena na koži, UZV vlastitih bubrega, ginekološki pregled PAPA testom, kontrolirati alfa-fetoprotein kod pacijenata s kroničnim virusnim hepatitisom B ili C te UZV dojki i mamografiju ${ }^{98}$. Najvažniji je postupak prevencije koju treba provesti sam pacijent, poput izbjegavanja UV zraka, smanjenje tjelesne težine, prestanka pušenja i fizičke aktivnosti. Liječenje zloćudnih bolesti u pacijenata s presađenim organom treba biti individualno i u suradnji s onkologom. Modifikacija imunosupresijskog protokola igra veliku ulogu u liječenju ovih pacijenata, uz specifično liječenje pojedinog tumora ${ }^{99}$. Postoje tri opcije modifikacije, a prva je potpuno ukidanje imunoterapije, graftektomija i nastavak liječenja dijalizom. Druga je smanjiti intenzitet imunosupresije, obično ukidanjem inhibitora kalcineurina ili smanjivanjem doze lijeka, dok je treća opcija uvođenje mTOR inhibitora umjesto inhibitora kalcineurina ${ }^{100-106}$. Potpuno ukidanje inhibitora kalcineurina povećava rizik od akutnog odbacivanja, dok mTOR inhibitori imaju povoljne učinke na sprječavanje rasta tumora ${ }^{100-102}$. Farmakogenomska istraživanja pokazuju da $26 \%$ ljudskih tumora ima molekularne signalne putove koji su pod utjecajem mTOR inhibitora. Relativno visok udio karcinoma jajnika (41\%), ali i karcinom pluća, kolona, limfoma i karcinoma dojke ima izraženu mTOR aktivnost. U karcinomima bubrega upravo je izražena mTOR aktivnost negativan prognostički čimbenik ${ }^{1,103}$.
U Kliničkom bolničkom centru Zagreb imamo razvijen sustavni probir pacijenata, kako na zloćudne tumore tako i na ostale komplikacije imunosupresijske terapije. Pacijenti dobivaju tzv. Dnevnik poslijetransplantacijskog praćenja s popisom pretraga koje treba ponavljati prema postupniku u određenim vremenskim periodima, uz individualizaciju prema čimbenicima rizika svakog pacijenta. Takvim se pristupom zloćudne bolesti otkrivaju u ranom stadiju ${ }^{109-112}$.

\section{ZAKLJUČAK}

Tumori su treći najčešći uzrok smrti nakon transplantacije bubrega. Čimbenici rizika su multipli i uključuju genetiku, okoliš, poremećaj imunosnog nadzora, virusne infekcije, intenzitet i trajanje imunosupresije, ali i vrijeme liječenje dijalizom. Tumori kože najčešće su neoplazme nakon transplantacije bubrega. Poslijetransplantacijska limfoproliferativna bolest najčešći je tumor u djece $s$ transplantiranim bubregom i drugi po učestalosti u populaciji odraslih pacijenata u većini transplantacijskih centara, no ne i našim centrima, što upućuje na razlike u imunosupresiji. Neophodno je potreban probir pacijenata, kako prije tako i nakon transplantacije, kao i dobar probir darovatelja. Liječenje pacijenata s presađenim bubregom koji razviju zloćudni tumor uključuje modifikaciju imunosupresivne terapije i specifično onkološko liječenje. Pristup toj skupini pacijenata mora biti putem multidisciplinarnog tima, kako bi se postigao optimalan rezultat liječenja.

Izjava o sukobu interesa: Autori izjavljuju da ne postoji sukob interesa.

\section{LITERATURA}

1. Bašić Jukić N, Kaštelan Ž. Transplantacija bubrega. Zagreb: Medicinska Naklada, 2016; 376-92.

2. Doycheva I, Amer S, Kymberly D, Watt KD. De Novo Malignancies After Transplantation. Med Clin N Am 2016; 100:551-67.

3. Gallagher MP, Kelly PJ, Jardine M, Perkovic V, Cass A, Craig JC et al. Long-term cancer risk of immunosuppressive regimens after kidney transplantation. J Am Soc Nephrol 2010;21:852-8.

4. Villeneuve PJ, Schaubel DE, Fenton SS, Shepherd FA, Jiang Y, Mao Y. Cancer incidence among Canadian kidney transplant recipients. Am J Transplant 2007;7:941-8.

5. Collett D, Mumford L, Banner NR, Neuberger J, Watson C. Comparison of the incidence of malignancy in recipients of different types of organ: a UK registry audit. Am J Transplant 2010;10:1889-96. 
6. Borel JF. History of the discovery of cyclosporin and of its early pharmacological development.Wien Klin Wochenschr 2002;114:433-7.

7. Kes $\mathrm{P}, \mathrm{Bašić} \mathrm{Jukić} \mathrm{N}$. Current trends in renal transplant immunosuppression. Acta Med Croatica 2006;60:243-9.

8. Birkleland SA, Lokkegaard $\mathrm{H}$, Storm $\mathrm{HH}$. Cancer risk in patients on dialysis and after renal transplantation. Lancet 2000;355:1886-7.

9. Danpanich E, Kasiske BL. Risk factors for cancer in renal transplant recipients. Transplantation 1999;68:1859-64.

10. Pedotti P, Cardillo M, Rossini G, Arcuri V, Boschiero L, Caldara $R$ et al. Incidence of cancer after kidney transplant: results from the North Italy Transplant Program. Transplantation 2003;76:1448-51.

11. Wong G, Turner RM, Chapman JR, Howell M, Lim WH, Webster AC et al, Time on dialysis and cancer risk after kidney transplantation. Transplantation 2013;95:114-21.

12. Opelz G, Dohler B. Influence of current and previous smoking on cancer and mortality after kidney transplantation. Transplantation 2016;100:227-32.

13. Baldo P, Cecco S, Giacomin E, Lazzarini R, Ros B, Marastoni S. mTOR pathway and mTOR inhibitors as agents for cancer therapy. Curr Cancer Drug Targets 2008;8:64765.

14. Adami J, Gabel H, Lindelof, B, Adami J, Gabel H, Lindelof $B$ et al. Cancer risk following organ transplantation: a nationwide cohort study in Sweden. Br J Cancer 2003;89: 1221-27.

15. Danpanich E, Kassiske BL. Risk factors for cancer in renal transplant recipients. Transplantation 1999;68:1859-64.

16. Gallagher MP, Kelly PJ, Jardine M, Perkovic V, Cass A, Craig JC et al. Long-term cancer risk od immunosuppressive regimens after kidney transplantation. J Am Soc Nephrol 2010; 21:852-8.

17. Piselli P, Serraino D, Segoloni GP, Sandrini S, Piredda GB, Scolari MP et al. Risk of de novo cancers after transplantation: results from a cohort of 7217 kidney transplant recipients, Italy 1997-2009. Eur J Cancer 2013;49:33644

18. ERA-EDTA Registry. ERA-EDTA Registry Annual Report 2016. Amsterdam: Academic Medical Center, Department of Medical Informatics. 2018. Available from: https://www.era-edta-reg.org/index.jsp?p=14.

19. Carrel A. The transplantation of organs. New York Times. April 14, 1914.

20. Kramer A, Pippias M, Stel VS, Bonthuis M, Abad Diez JM, Afentakis $\mathrm{N}$ et al. Renal replacement therapy in Europe: a summary of the 2013 ERA-EDTA Registry Annual Report with a focus on diabetes mellitus. Clin Kidney J 2016;9:457-69.

21. Pippias M, Kramer A, Noordzij M, Afentakis N, Abad Diez JM, Alonso de la Torre R et al. The European Renal Association-European Dialysis and Transplant Association Registry Annual Report 2014: a summary. Clin Kidney J 2017;10:154-69.

22. Australian and New Zealand Dialysis and Transplant Registry. The 30th Annual Report. 2007 Feb 1. Available from: https://www.anzdata.org.au/anzdata/.

23. Wong G, Chapman JR. Cancers after renal transplantation. Transplant Rev (Orlando) 2008;22:141-9.

24. Engels EA, Pfeiffer RM, Fraumeni JF Jr, Kasiske BL, Israni AK, Snyder JJ, Wolfe RA et al. Spectrum of cancer risk among US solid organ transplant recipients. JAMA 2011; 306:1891-901.

25. Wong G, Au E, Badve SV, Lim WH. Breast Cancer and Transplantation. Am J Transplant 2017;17:2243-53.

26. Matas AJ, Gillingham KJ, Humar A, Kandaswamy R, Sutherland DE, Payne WD et al. 2202 kidney transplant recipients with 10 years of graft function: what happens next?. Am J Transplant 2008;8:2410-9.

27. Desai R, Collett D, Watson C, Johnson P, Evans T, Neuberger J. Risk of recurrence of pre-existing cancer in organ recipients (abstract). Am J Transplant 2013;13(Suppl 5).

28. Cognard N, Anglicheau D, Gatault P. Recurrence of Renal Cell Cancer After Renal Transplantation in a Multicenter French Cohort. Transplantation 2018;102:860-7.

29. Cherikh WS, Kauffmann HM, Delmonico FL. A multivariate analysis of discharge immunosuppression and posttransplant malignancy. Am J Transplant 2001;1(Suppl 1):353A.

30. Alberu J, Pascoe MD, Campistol JM, Schena FP, Rial Mdel $\mathrm{C}$, Polinsky $\mathrm{M}$ et al. Lower malignancy rates in renal allograft recipients converted to sirolimus-based, calcineurin inhibitor-free immunotherapy: 24-Month results from the CONVERT trial. Transplantation 2011;92:303-10.

31. Seukeran DC, Newstead CG, Cunliffe WJ. The compliance of renal transplant recipients with advice about sun protection measures. Br J Dermatol 1998;138:301-3.

32. Guba M, Graeb C, Jauch KW, Geissler EK. Pro- and anticancer effects of immunosuppressive agents used in organ transplantation. Transplantation 2004;77:1777-82.

33. Penn I, First MR. Development and incidence of cancer following cyclosporine therapy. Transplant Proc 1986;18: 210-5.

34. Vajdic CM, McDonald SP, McCredie MR, van Leeuwen MT, Stewart JH, Law M et al. Cancer incidence before and after kidney transplantation. JAMA 2006;296:282331.

35. Penn I. Evaluation of transplant candidates with pre-existing malignancies. Ann Transplant 1997;2:14-7.

36. Penn I. Cancers in renal transplant recipients. Adv Ren Replace Ther 2000;7:147-56.

37. Bubić-Filipi Lj. Bašić Jukić $N$, Pasini J, Kaštelan Z, Kes $P$. Clinical features of Kaposi's sarcoma in Croatian renal transplant recipients. Prilozi 2009;30:175-84.

38. al-Sulaiman $\mathrm{MH}$, al-Khader AA. Kaposi's sarcoma in renal transplant recipients. Transplant Sci 1994;4:46-60.

39. Bouwes Bavinck JN, Hardie DR, Green A, Cutmore S, MacNaught A, O'Sullivan B et al. The risk of skin cancer in renal transplant recipients in Queensland, Australia. A follow-up study. Transplantation 1996;61:715-21.

40. Cathomas G, Tamm M, McGandy CE, Itin PH, Gudat F, Thiel $G$ et al. Transplantation-associated malignancies: restriction of human herpes virus 8 to Kaposi's sarcoma. Transplantation 1997;64:175-8.

41. Dreno B. Skin cancer after transplantation. Nephrol Dial Transplant 2003;18:1052-8.

42. Gotti E, Remuzzi G. Post-transplant Kaposi's sarcoma. J Am Soc Nephrol 1997;8:130-7.

43. Bašić Jukić $\mathbf{N}$, Kes $\mathrm{P}$, Ćorić $\mathrm{M}$, Kaštelan Z, Pasini J, BubićFilipi L. Posttransplant lymphoproliferative disorder in the wall of a lymphocele: a case report. Transplant Proc 2009;41:1966-8. 
44. Bašić Jukić N, Kes P, Bubić-Filipi L, Ćorić M. An unusual case of forehead post-transplant lymphoproliferative disease. Kidney Int 2008;73:136.

45. Opelz G, Döhler B. 2004. Lymphomas after solid organ transplantation: A collaborative transplant study report. Am J Transplant 2004;4:222-30.

46. Penn I. Incidence and tretment of neoplasia after transplantation. J Heart Lung Transplant 1993;12:S328-36

47. Bašić Jukić N, Hršak-Puljić I, Kes P. Renal transplantation in patients with Balkan endemic nephropathy. Transplant Proc 2007;39:1432-5.

48. Jelaković B, Nikolić J, Radovanović Z, Nortier J, Cosyns JP, Grollman AP et al. Consensus statement on screening, diagnosis, classification and treatment of endemic (Balkan) nephropathy. Nephrol Dial Transplant 2014;29: 2020-7.

49. Wong G, Howard K, Webster AC, Chapman JR, Craig JC. Screening for renal cancer in recipients of kidney transplants. Nephrol Dial Transplant 2011;26:1729-39.

50. Euvrard S, Kanitakis J, Claudy A. Skin cancers after organ transplantation. N Engl J Med 2003;348:1681-91.

51. Lindelof B, Sigurgeirsson B, Gabel H, Stern RS. Incidence of skin cancer in 5356 patients following organ transplantation. Br J Dermatol 2000;143:513-9.

52. Hartevelt MM, Bavinck JN, Kootte AM, Vermeer BJ, Vandenbroucke JP. Incidence of skin cancer after renal transplantation in The Netherlands. Transplantation 1990;49:506-9.

53. Bašić Jukić $N$, Furić-Čunko V, Ćorić $M$, Bubic-Filipi LJ, Kastelan Z, Pasini J et al. Appendiceal carcinoid and mucinous cystadenoma in renal transplant recipients: case reports. Transplant Proc 2010;42:1704-7.

54. Luengrojanakul $\mathrm{P}$, Vareesangthip $\mathrm{K}$, Chainuvati T, Murata $\mathrm{K}$, Tsuda $\mathrm{F}$, Tokita $\mathrm{H}$ et al. Hepatitis $\mathrm{C}$ virus infection in patients with chronic liver disease or chronic renal failure and blood donors in Thailand. J Med Virol 1994;44: 287-92.

55. Libertiny G, Watson CJ, Gray DW, Welsh KI, Morris PJ et al. Rising incidence of post-transplant lymphoproliferative disease in kidney transplant recipients. $\mathrm{Br} J$ Surg 2001;88:1330-4.

56. Caillard S, Dharnidharka V, Agodoa L, Bohen E, Abbott K. Posttransplant lymphoproliferative disorders after renal transplantation in the United States in era of modern immunosuppression. Transplantation 2005;80:1233-43.

57. Frances C, Mouquet C, Marcelin AG, Barete S, Agher R, Charron $D$ et al. Outcome of kidney transplant recipients with previous human herpesvirus- 8 infection. Transplantation 2000;69:1776-9.

58. Mbulaiteye SM, Engels EA. Kaposi's sarcoma risk among transplant recipients in the United States (1993-2003). Int J Cancer 2006;119:2685-91.

59. Shepherd FA, Maher E, Cardella C, Cole E, Greig P, Wade JA et al. Treatment of Kaposi's sarcoma after solid organ transplantation. J Clin Oncol 1997;15:2371-7.

60. Duman S, Toz H, Asci G, Alper S, Ozkahya M, Unal I et al. Successful treatment of post-transplant Kaposi's sarcoma by reduction of immunosuppression. Nephrol Dial Transplant 2002;17:892-6.

61. Cattaneo D, Gotti E, Perico N, Bertolini G, Kainer G, Remuzzi G. Cyclosporine formulation and Kaposi's sarcoma after renal transplantation. Transplantation 2005;80: 743-8.
62. Stallone G, Schena A, Infante B, Di Paolo S. Sirolimus for Kaposi's sarcoma in renal-transplant recipients. $\mathrm{N}$ Engl J Med 2005;352:1317-23.

63. Sanchez-Fructuoso A, Conesa J, Perez Flores I, Gómez Alamillo C, Calvo Romero N, Arias M et al. Conversion to sirolimus in renal transplant patients with tumors. Transplant Proc 2006;38:2451-2.

64. Mohsin N, Budruddin M, Pakkyara A, Darweesh A, Nayyer $\mathrm{M}$, Amitabh J et al. Complete regression of visceral Kaposi's sarcoma after conversion to sirolimus. Exp Clin Transplant 2005;3:366-9.

65. Lebbe C, Euvrard S, Barrou B, Pouteil-Noble C, Garnier JL, Glotz D et al. Sirolimus conversion for patients with posttransplant Kaposi's sarcoma. Am J Transplant 2006; 6:2164-8.

66. Volkow P, Zinser JW, Correa-Rotter R. Molecularly targeted therapy for Kaposi's sarcoma in a kidney transplant patient: Case report, "what worked and what did not.". BMC Nephrol 2007;8:6.

67. Sakhuja V, Ramachandran R, Kohli HS, Jha V, Gupta KL, Rathi $\mathrm{M}$ et al. Spectrum of lymphoproliferative disorders following renal transplantation in North India. Indian J Nephrol 2013;23:287-91.

68. Opelz G, Henderson R. Incidence of non-Hodgkin lymphoma in kidney and heart transplant recipients. Lancet 1993;342:1514-6.

69. Faull RJ, Hollett P, McDonald SP. Lymphoproliferative disease after renal transplantation in Australia and New Zealand. Transplantation 2005;80:193-7.

70. Boubenider S, Hiesse C, Goupy C, Kriaa F, Marchand S, Charpentier $B$. Incidence and consequences of posttransplantation lymphoproliferative disorders. J Nephrol 1997;10:136-45.

71. Bates WD, Gray DW, Dada MA, Chetty R, Gatter KC, Davies DR et al. Lymphoproliferative disorders in Oxford renal transplant recipients. J Clin Pathol 2003; 56:439-46.

72. Penn I. Cancers complicating organ transplantation. N Engl J Med 1990;323:1767-9.

73. Clarke CA, Robbins HA, Tatalovich Z, Lynch CF, Pawlish $\mathrm{KS}$, Finch JL et al. Risk of merkel cell carcinoma after solid organ transplantation. J Natl Cancer Inst 2015;107: dju382.

74. Penn I. Primary kidney tumors before and after renal transplantation. Transplantation 1995;59:480-5.

75. Penn I. Occurrence of cancers in immunosuppressed organ transplant recipients. Clin Transpl 1998;147-58.

76. Prajwal D, Smith G, Krishmita S, Supratik R, Vijaya RB. Renal Cancer in Recipients of Kidney Transplant. Rare Tumors 2017;9: 6550.

77. Pedotti P, Poli F, Longhi E, Frison S, Caldara R, Chiaramonte $S$ et al. Epidemiologic study on the origin of cancer after kidney transplantation. Transplantation 2004;77:426-8.

78. Morath C, Mueller M, Goldschmidt H, Schwenger V, Opelz G, Zeier M. Malignancy in renal transplantation. J Am Soc Nephrol 2004;15:1582-8.

79. Yan L, Chen P, Chen EZ, Gu A, Jiang ZY. Risk of bladder cancer in renal transplant recipients: a meta-analysis. $\mathrm{Br}$ J Cancer 2014;110:1871-7.

80. Li WH, Chen YJ, Tseng WC, Lin MW, Chen TJ, Chu SY, Hwang $\mathrm{CY}$ et al. Malignancies after renal transplantation in Taiwan: a nationwide population-based study. Nephrol Dial Transplant 2012;27:833-9. 
81. Thon WF, Kliem V, Truss MC, Anton P, Kuczyk M, Stief CG et al. De novo urothelial carcinoma of the upper and lower urinary tract in kidney - transplant patients with endstage analgesic nephropathy. World J Urol 1995;13:254-61.

82. Blohme I, Johansson S. Renal pelvic neoplasms and atypical urothelium in patients with end-stage analgesic nephropathy. Kidney Int 1981;20:671-5.

83. Karamchandani D, Arias-Amaya R, Donaldson N, Gilbert J, Schulte KM. Thyroid cancer and renal transplantation: a meta-analysis. Endocr Relat Cancer 2010;17:159-67.

84. Kitahara CM, Yanik EL, Ladenson PW, Hernandez BY, Lynch CF, Pawlish KS et al. Risk of thyroid cancer among solid organ transplant recipients. Am J Transplant 2017; 17:2911-21.

85. Agaimy $\mathrm{A}$, Wünsch PH. Gastrointestinal stromal tumours (GIST) in kidney transplant recipients--a report of two cases. Nephrol Dial Transplant 2007;22:1489-90.

86. Sertac C, Sanem G, Romuald P, and Ian A. Gastrointestinal stromal tumour in a recipient with kidney transplantation. BMJ Case Rep 2015;2015:bcr2014207178.

87. Tu H, Li Q, Cai J, Chen Z, Yang $\mathrm{H}$, Jiang $\mathrm{H}$ et al. Extragastrointestinal stromal tumor in a kidney transplant recipient. Clin Exp Nephrol 2012;16:350-3.

88. Hong $\mathrm{Y}, \mathrm{Xu} \mathrm{M}, \mathrm{Yu} \mathrm{B}$, Chen $\mathrm{P}$, Shi $\mathrm{X}$, Yang $\mathrm{H}$ et al. The correlation between renal transplantation and liver carcinoma: a meta-analysis. Oncotarget 2017;8:68928-37.

89. Montalto G, Cervello M, Giannitrapani L, Dantona F, Terranova A, Castagnetta LA. Epidemiology, risk factors, and natural history of hepatocellular carcinoma. Ann $\mathrm{N} \mathrm{Y}$ Acad Sci 2002;963:13-20.

90. Cheung CY, Lam MF, Chu KH, Chow KM, Tsang KY, Yuen SK et al. Malignancies after kidney transplantation: Hong Kong renal registry. Am J Transplant 2012;12:3039-46.

91. Hwang EA, Kang MJ, Han SY, Park SB, Kim HC. Viral infection following kidney transplantation: long-term followup in a single center. Transplant Proc 2004;36:2118-9.

92. Huang CC, Liaw YF, Lai MK, Chu SH, Chuang CK, Huang JY. The clinical outcome of hepatitis $C$ virus antibody-positive renal allograft recipients. Transplantation 1992;53: 763-5.

93. Squadrito G, Spinella R, Raimondo G. The clinical significance of occult HBV infection. Ann Gastroenterol 2014; 27:15-9.

94. Gomaa Al, Khan SA, Toledano MB, Waked I, Taylor-Robinson SD. Hepatocellular carcinoma: Epidemiology, risk factors and pathogenesis. World J Gastroenterol 2008;14: 4300-8.

95. Park JM, Choi MG, Yang CW, Jung CK, Lee SK, Yoon AR et al. Increased incidence of gastric cancer in renal transplant recipients. J Clin Gastroenterol 2012;46:e87-91.

96. Saleeb R, Faragalla $H$, Yousef GM, Stewart R, Streutker CJ. Malignancies in a renal transplant population: The St. Michael's Hospital experience. Urol Ann 2016;8:163-7.

97. D'Souza G, Kreimer AR, Viscidi R, Pawlita M, Fakhry C, Koch WM et al. Case-control study of human papillomavirus and oropharyngeal cancer. N Engl J Med 2007;356:1944-56.
98. Grulich $\mathrm{AE}$, van Leeuwen $\mathrm{MT}$, Falster MO, Vajdic $\mathrm{CM}$. Incidence of cancers in people with HIV/AIDS compared with immunosuppressed transplant recipients: a metaanalysis. Lancet 2007;370:59-67.

99. Chin-Hong P. Human Papillomavirus in Kidney Transplant Recipients. Semin Nephrol 2016;36:397-404.

100. Stallone G, Infante B, Grandaliano G. Management and prevention of post-transplant malignancies in kidney transplant recipients. Clin Kidney J 2015;8:637-44.

101. Tremblay F, Fernandes M, Habbab F, deB Edwardes MD, Loertscher R, Meterissian S. Malignancy after renal transplantation: incidence and role of type of immunosuppression. Ann Surg Oncol 2002;9:785-8.

102. Dantal J, Hourmant M, Cantarovich D, Giral M, Blancho $G$, Dreno B et al. Effect of long-term immunosuppression in kidney-graft recipients on cancer incidence: randomized comparison of two cyclosporin regimens. Lancet 1998;351:623-8.

103. Gruber SA, Gillingham K, Sothern RB, Stephanian E, Matas AJ, Dunn DL. De novo cancer in cyclosporine-treated and non-cyclosporine-treated adult primary renal allograft recipients. Clin Transplant 1994;8:388-95.

104. McGeown MG, Douglas JF, Middleton D. One thousand renal transplants at Belfast City Hospital: post-graft neoplasia 1968-1999, comparing azathioprine only with cyclosporin-based regimes in a single centre. Clin Transpl 2000: 193-202.

105. Wullschleger S, Loewith R, Hall MN. TOR signaling in growth and metabolism. Cell 2006;124:471-84.

106. Luan FL, Hojo M, Maluccio M, Yamaji K, Suthanthiran M. Rapamycin blocks tumor progression: unlinking immunosuppression from antitumor efficacy. Transplantation 2002;73:1565-72.

107. Vignot S, Faivre S, Aguirre D, Raymond E. mTOR-targeted therapy of cancer with rapamycin derivatives. Ann Oncol 2005;16:525-37.

108. Koehl GE, Andrassy J, Guba M, Richter S, Kroemer A, Scherer MN et al. Rapamycin protects allografts from rejection while simultaneously attacking tumors in immunosuppressed mice. Transplantation 2004;77:1319-26.

109. Juric I, Basic-Jukic N. Multiple primary malignancies: the first case of a combination of a gastrointestinal stromal tumor and renal cell carcinoma in a kidney transplant recipient. Transplant Proc 2019;51:3070-1.

110. Basic-Jukic N, Mesar I, Kirincich J. Cutaneous metastasis as a presenting feature of renal adenocarcinoma in a renal transplant recipient: a case report. Transplant Proc 2019;51:3072-3.

111. Borlinić T, Knežević T, Gellineo L, Franceschi M, Bukvić Mokos Z, Bašić-Jukić N. Melanomas in renal transplant recipients: a single-center study. Acta Dermatovenerol Croat 2017;25:281-4.

112. Basic-Jukic N, Kirincich J, Jelakovic B, Kastelan Z. Multiple primary malignancies in renal transplant recipients: a single centre retrospective cohort study. Kidney Blood Press Res 2018;43:1034-41. 